\title{
THE EXCHANGE RATES - INDICATORS FOR ASSESSING THE FINANCIAL PERFORMANCE OF THE COMPANIES FROM ROMANIA
}

\author{
Baltes Nicolae PhD \\ "Lucian Blaga" University of Sibiu \\ E-mail: baltes_n@yahoo.com \\ Dragoe Alexandra-Gabriela-Maria PhD Student \\ "Lucian Blaga" University of Sibiu \\ E-mail: sandra_19_2008@yahoo.com
}

(Received November 2015; Accepted January 2016)

\begin{abstract}
The research aims to determine the financial performance of the companies listed and traded on the Bucharest Stock Exchange from the manufacturing sector in Romania, compared with the performance recorded by the Bucharest Stock Exchange, based on the exchange rates. It was concluded that the financial performance of the companies included in the research, quantified on the basis of the exchange rates, decreased significantly with the arrival of the financial and economic crisis, currently, the companies being unable to reach the level of performance recorded before the crisis.
\end{abstract}

Key words: performance, exchange rates, simple linear regression, Pearson correlation coefficient.

Jel codes: $\mathrm{C} 1, \mathrm{C} 12, \mathrm{G} 10$.

\section{Introduction}

The economic and financial crisis that started in 2008 influenced the stock markets of the world, and determined the reduction of the risk that the investors are willing to assume. Also, the volume of the transactions and of the profits obtained by the investors was reduced. Since 2008, the financial performance assessed on the basis of the exchange rates has been considerably reduced on the Romanian capital market. The economic and financial crisis represents also the state of the economy characterized by decreases in gross domestic product, in investment processes, reduction of investment etc. (Marius Gust, 2014).

The research highlights the way that the crisis influenced the evolution of the most important exchange rates, at the level of the manufacturing industry from Romania, represented by 36 societies listed on the Bucharest Stock Exchange at the first and second tier, and also at the level of the whole Bucharest Stock Exchange.

The study is very important if we take into consideration the fact that the manufacturing industry owns in Romania the most important weight in the total number of the societies traded at the Bucharest Stock Exchange. The objective of 
this research is to calculate and interpret the market rates that are mostly used in financial analysis, with the aim to measure the company's performance.

\section{Literature review}

Among the most important stock index, that reveal the financial performance of a society, we can mention: Price Earnings Ratio (PER) and Market-to-book ratio (PBV).

a) The Price Earnings Ratio (PER) represents the ratio between the market price of the share and net income per share (Anghelache, 2009):

$$
P E R=\frac{\text { Market price of the share }}{\text { Net income per share }}
$$

According to Javier Estrada, 2005: "PER ratios are one of the valuation tools most widely used by analysts, and are the key variable in many value strategies".

Investors have long used PER, to help determine if stocks are reasonably priced (Shen, P., 2000). Generally, a relatively high PER reveals an expensive and probably overvalued share. When PER is low, the share is cheap and therefore it is recommended to purchase it (http://www.biblioteca-digitala.ase.ro/biblioteca/ carte2. asp? $i d=277 \& i d b=)$.

In a static approach it is normal that a share with a low PER to be preferred by the investors more than one with a high PER, but the current profit reached by the share can be very different from its future profits. As a consequence, the PER analysis must also take into account the evolution of the future profits brought by the share.

b) TheMarket-to-book ratio (PBV) represents another ratio widely used on the capital markets. It is determined as ratio between the market price of the share and its book value (Kenneth Marangu, 2014):

$$
\text { PER }=\frac{\text { Market price of the share }}{\text { The book value of the share }}
$$

The market-to-book ratio represents one of the most important factors that influence the stock market performance (Ruthenberg, D., Pearl, S., Landskroner, Y., 2011).

The book value of the share is determined as ratio between the equity and the total number of shares (Baltes, 2014). The economists believe that a low PBV provide a "safety margin", many investors avoiding the shares with a high PBV when making a portfolio. 
Other specialists believe that a company with an efficient management will have a market value higher than the historical value of its assets (Baltes, N.,Dragoe, A. G. M., Ardelean, D. I., 2014).

The research also studies the correlation between the annual average of the PER and the operational result of the manufacturing industry from Romania, determined through a simple linear regression that highlights a relationship between the two variables, by the following type (Tichindelean, 2014):

where,

$$
y i=a+b^{*} x i
$$

yi $=$ the dependent variable

$\mathrm{xi}=$ the independent variable

$\mathrm{a}, \mathrm{b}=$ the regression model parameters

In order to identify the linear correlation between the annual mean of the PER of the manufacturing industry from Romania and the annual mean of the operational result of the same industry, we used the Pearson correlation coefficient (Tichindelean, 2014):

where,

$$
r=r_{x y}=\frac{n \sum x_{i} y_{i}-\sum x_{i} \sum y_{i}}{\sqrt{n \sum x_{i}^{2}-\left(\sum x_{i}\right)^{2}} \sqrt{n \sum y_{i}^{2}-\left(\sum y_{i}\right)^{2}}}
$$

$$
\begin{aligned}
& r=\text { the Pearson correlation coefficient } \\
& n=\text { the number of analysed years } \\
& y=\text { the dependent variable (PER) } \\
& \mathrm{x}=\text { the independent variable (the operational result) }
\end{aligned}
$$

Pearson's correlation coefficient was discovered by Bravais in 1846, but Karl Pearson was the first that described, in 1896, the method of its determination (Hauke J., Kossowski T., 2011).

It is not difficult to calculate and interpret it, therefore it is a good measure of the association in the majority of applied practice (Clark, M., 2013).

The Pearson coefficient can record values between -1 and 1 . Positive values of the coefficient highlight a positive correlation between the variables, while negative values highlight an inverse correlation. The correlations are more intense as the coefficient values are closer to 1 or -1 (Lilea, 2006).

\section{Research methodology}

The researched population is formed by 36 societies from the manufacturing industry in Romania, listed on the Bucharest Stock Exchange at the first and second tier, over a period of 8 years (2007 - 2014). We selected this industry for 
several reasons, the main consisting of the high percentage of the societies that belong to it in the total number of the societies listed at the Bucharest Stock Exchange. At the same time, we considered that the manufacturing industry has great potential that could improve the country's economic and financial situation. Unfortunately, this potential is not yet valued at its fair value.

The research involved collecting primary data from the annual financial statements and from the annual management reports of the analysed societies. The data was collected from the Bucharest Stock Exchange (www.bvb.ro) site and from the sites of the analysed societies. Then, we developed a simple linear regression between the analysed variables, namely: the annual average of the PER and of the operational result of the manufacturing industry, the ANOVA (Analysis of Variance) test, we determined the Pearson correlation coefficient and the standardized and unstandardized coefficients, using Microsoft Excel and the SPSS Statistics program.

4. Case study regarding the evolution of the society's financial performance evaluated through the exchange rates. Results and discussions

The table no.1 highlights on the one hand, the evolution of the number of societies listed during the period 2007-2014, and on the other hand, the relatively high weight of the societies belonging to the manufacturing industry in the total number of listed societies. It can be noticed the fact that the weight remained almost constant during the whole period, the societies from the manufacturing industry representing over $40 \%$ of the total number of listed societies.

Table no.1. The weight of the societies from the manufacturing industry in the total number of the listed societies

\begin{tabular}{|l|c|c|c|c|c|c|c|c|}
\hline & $\mathbf{2 0 0 7}$ & $\mathbf{2 0 0 8}$ & $\mathbf{2 0 0 9}$ & $\mathbf{2 0 1 0}$ & $\mathbf{2 0 1 1}$ & $\mathbf{2 0 1 2}$ & $\mathbf{2 0 1 3}$ & $\mathbf{2 0 1 4}$ \\
\hline $\begin{array}{l}\text { The number of all the societies listed on } \\
\text { the Bucharest Stock Exchange }\end{array}$ & 59 & 68 & 69 & 74 & 79 & 79 & 83 & 83 \\
\hline $\begin{array}{l}\text { The number of the societies from the } \\
\text { manufacturing industry listed on the } \\
\text { Bucharest Stock Exchange }\end{array}$ & 26 & 28 & 30 & 32 & 35 & 35 & 36 & 36 \\
\hline $\begin{array}{l}\text { The weight of the societies from the } \\
\text { manufacturing industry/all the societies } \\
\text { listed (\%) }\end{array}$ & 44 & 41 & 43 & 43 & 44 & 44 & 43 & 43 \\
\hline
\end{tabular}

Source: Authors own processing of the data collected from the annual financial statements of the analysed societies, published on the site of the Bucharest Stock Exchange (www.bvb.ro) and on the site of the analysed societies.

The values of the PER ratio record oscillating evolutions during the investigated period. After a significant decrease in 2008 , the ratio considerably recovers, in the following two years recording values superior to the average recorded in 2007. The values recorded in 2009-2010, but also in 2012 and 2014, reveal the fact that the 
shares of the societies from this industry are generally expensive, and probably overvalued, As a consequence, it is not recommended to purchase them in that period.

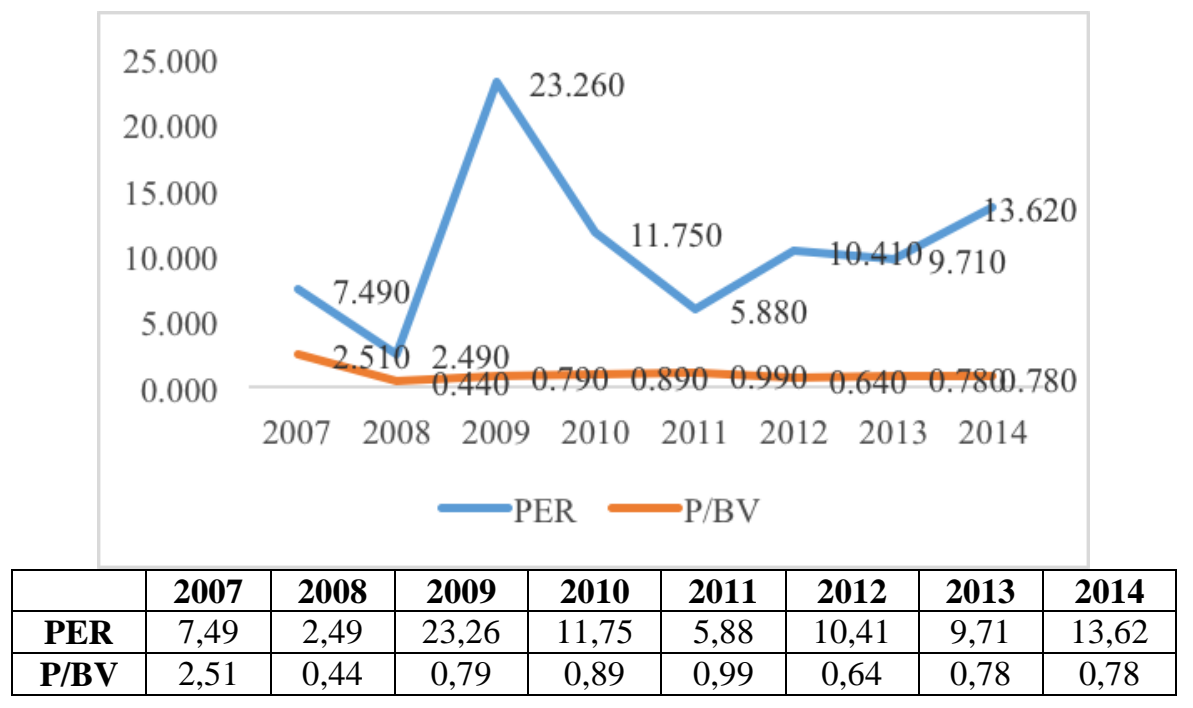

Figure no. 1. The PER and PBV evolution at the level of the manufacturing industry from Romania, during the period 2007-2014

Source: Authors own processing of the data collected from the annual financial statements of the analysed societies, published on the site of the Bucharest Stock Exchange (www.bvb.ro) and on the site of the analysed societies

Concerning the PBV ratio, we can notice a strong decrease at the same time with the economic and financial crisis arrival. From 2009 to 2011, a slight increase can be noticed, followed by a decrease during the period 2012 - 2014, without returning to the value recorded in 2007 (before the financial crisis).

The evolution of the society's market capitalization is presented in figure no.2.

The market capitalization of the societies from the manufacturing industry decreased significantly in the years of the crisis 2008 and 2009, in comparison with 2007. Since 2010, the market capitalization records moderate increases, exceeding in the years 2013 and 2014, the amount recorded in 2007.

In the case study, we also planned to identify the existence of a relationship between the annual average of the PER and the operational result of the manufacturing industry from Romania. During the period 2007 - 2014, it was determined through the statistic program SPSS and Microsoft Excel, a simple 
Baltes, N., Dragoe, A. (2016)

The exchange rates - indicators for assessing the financial performance of the companies from Romania

linear regression between the two variables, on the basis of the Pearson correlation coefficient.

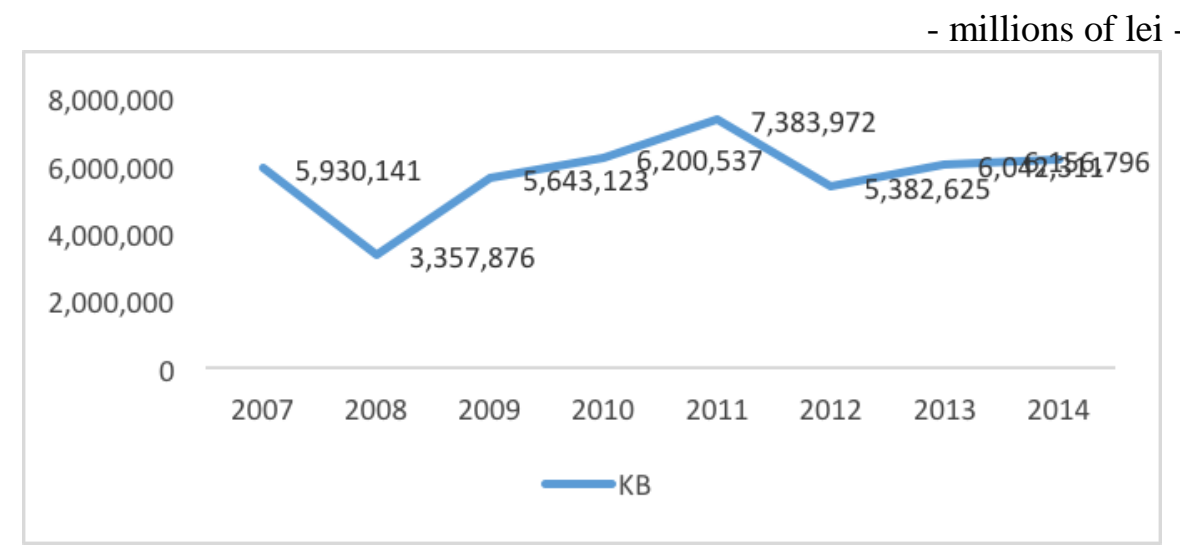

Figure no. 2. The evolution of the annual average of the market capitalization in the manufacturing industry from Romania, during the period 2007-2014

Source: Authors own processing of the data collected from the annual financial statements of the analysed societies, published on the site of the Bucharest Stock Exchange (www.bvb.ro) and on the site of the analysed societies

In order to establish the existence of a relationship between the variables, we took into account two scenarios, namely the null hypothesis ( $\mathrm{H} 0)$ and the alternative hypothesis (H1) and finally, we validated the correct one.

The null hypothesis ( $\mathrm{HO})$ assumes that there is no relationship between the annual average of the PER and of the operational result of the manufacturing industry from Romania, and the alternative hypothesis (H1) assumes that there is a relationship between the two variables.

In order to prove the existence or the inexistence of a relationship between the annual average of the PER and the operational result of the manufacturing industry from Romania, the Pearson correlation coefficient was determined that highlights the size of the change of a variable as consequence to the change of another variable (Catoiu, 2009).

The correlation coefficient is $-0,71$, value that indicates a negative correlation between the two variables. Therefore, an increase in the operational result will determine a PER decrease and vice versa.

In order to issue a deeper analysis of the correlation between the two variables, the simple linear regression method was used. (Table no. 3). 


\begin{tabular}{|c|c|c|c|}
\hline \multicolumn{4}{|c|}{ Table no. 2. The Pearson correlation coefficient calculation } \\
\hline & & PER & Rezexpl \\
\hline \multirow{4}{*}{$\begin{array}{l}\text { Pearson Correlation } \\
\text { Sig. (1-tailed) }\end{array}$} & PER & 1,000 &,- 710 \\
\hline & Rezexpl &,- 710 & 1,000 \\
\hline & PER & & ,024 \\
\hline & Rezexpl &, 024 & \\
\hline \multirow{2}{*}{$\mathrm{N}$} & PER & 8 & 8 \\
\hline & Rezexpl & 8 & 8 \\
\hline
\end{tabular}

Source: Authors own processing of the data collected from the annual financial statements using the SPSS statistic program

Table no. 3. The determination of the correlation PER - operational result through the simple linear regression method

\begin{tabular}{|c|r|r|r|r|r|r|r|r|r|}
\hline $\mathrm{R}$ & \multirow{2}{*}{$\begin{array}{c}\mathrm{R} \\
\text { Square }\end{array}$} & $\begin{array}{l}\text { Adjusted } \\
\text { R Square }\end{array}$ & $\begin{array}{l}\text { Std. Error of } \\
\text { the Estimate }\end{array}$ & $\begin{array}{l}\text { R Square } \\
\text { Change }\end{array}$ & $\begin{array}{c}\text { F } \\
\text { Change }\end{array}$ & df1 & df2 & $\begin{array}{c}\text { Sig. F } \\
\text { Change }\end{array}$ & Watson \\
\hline,$- 710^{\mathrm{a}}$ &, 504 &, 421 & 4,93429 &, 504 & 6,091 & 1 & 6 &, 049 & 2,293 \\
\hline
\end{tabular}

Source: Authors own processing of the data collected from the annual financial statements using the SPSS statistic program

The sign of the contingency coefficient $(\mathrm{R})$ highlights the sense of the correlation between the two variables, namely between the annual average of the PER and the operational result of the manufacturing industry in Romania. As in the analysis carried out on the basis of the Pearson correlation coefficient, it can be noticed the fact that between the two variables there is a negative correlation. The multiple coefficient of determination (R Square), that reveals the intensity of the correlation, demonstrates the existence of a medium correlation between the two variables (50.4\%). Therefore, 50,4\% from the PER's variance is caused by the variance of the operational result, and the rest of the variance (49.6\%) is caused by the residual variable $(\varepsilon)$. The value of the Adjusted R Square indicator is very close to the value of $\mathrm{R}$ Square, meaning that the regression model can be extended to the entire population researched (Field, 2005).

The standard error of the estimate is 4,93 , therefore in general, a value of the residual variable deviates from the average of the residual variable with 4,93 units. Durbin - Watson test is relevant in interpreting the lack of autocorrelation of the residual variable. In our research, we obtained a value of the Durbin - Watson test of 2,29, that allows the validation of the regression model that proved to be correct from the perspective of the lack of autocorrelation of the residual variable (Tichindelean, 2014).

$\mathrm{F}$ test reveals the statistical significance of the regression used in the research, by testing the null hypothesis that assumes that $\mathrm{R}$ Square is 0 .The predictive capacity 
of the $\mathrm{F}$ test is high, given the fact that $\mathrm{F}>1$. The higher the value of $\mathrm{F}$ is, the greater the degree of prediction of the model. In this case, $\mathrm{F}$ is 6,091 , and the probability that the model to be wrong $(4,9 \%)$ is low.

Table no. 4. The values of the estimated parameters of the regression model Coefficients ${ }^{\mathrm{a}}$

\begin{tabular}{|l|r|r|r|r|r|r|r|}
\hline Model & \multicolumn{2}{|c|}{$\begin{array}{c}\text { Unstandardized } \\
\text { Coefficients }\end{array}$} & $\begin{array}{c}\text { Standardized } \\
\text { Coefficients }\end{array}$ & \multirow{2}{*}{$\mathrm{t}$} & \multirow{2}{*}{ Sig. } & \multicolumn{2}{|c|}{\begin{tabular}{c}
\multicolumn{2}{|c|}{ In Confidence } \\
Interval for B
\end{tabular}} \\
\cline { 2 - 6 } & \multicolumn{1}{|c|}{ B } & Std. Error & Beta & & & $\begin{array}{c}\text { Lower } \\
\text { Bound }\end{array}$ & $\begin{array}{c}\text { Upper } \\
\text { Bound }\end{array}$ \\
\hline Constant & 14,983 & 2,373 & & 6,314 &, 001 & 9,177 & 20,790 \\
\hline Rezexpl & $-5,521 \mathrm{E}-007$ &, 000 &,- 710 & $-2,468$ &, 049 &, 000 &, 000 \\
\hline
\end{tabular}

a. Dependent Variable: PER

Source: Authors own processing of the data collected from the annual financial statements using the SPSS statistic program

The aim of the research is to determine the relationship between the two variables: the dependent variable (the annual average of the PER from the manufacturing industry in Romania) and the independent variable (the annual average of the operational result from the same industry).

On the basis of the simple linear regression, it was demonstrated the existence of a medium correlation between the variables. The existence of a linear regression between the two variables is also confirmed by the level of significance of the statistic test (Sig) that highlights the probability that the value of the t Student test to be caused by chance.

The $\mathrm{t}$ Student test reveals the influence of the estimated parameters on the dependent variable, namely on the PER. Also, it is very important to mention the fact that the value of the $t$ test is directly proportional with the influence of the operational result on the PER's value. Therefore, it is very important that the estimated parameters to be different from 0 . In our research, the estimated parameters are different from 0 , so they are influencing the PER. Sig is 0,049, therefore the probability that the value of the $t$ Student test to be caused by chance is below 5\%, so the alternative hypothesis $\mathrm{H} 1$ that also confirms the existence of a linear relationship between the two variables is valid.

\section{Conclusions}

The financial analysis that determined and identified the evolution of the most important exchange rates of the companies from the manufacturing industry in Romania and across all the companies traded on the Bucharest Stock Exchange has indicated the fact that the exchange rates didn't return to pre-crisis values. 
However, a constant increase in the last years of the analysed period can be noticed.

Using the simple linear regression, on the basis of the Pearson correlation coefficient, led to the conclusion that, the profitability, represented by the operational result, influences the PER of the researched companies. It was demonstrated the existence of a negative and medium correlation between the two analysed variables, the fluctuations of the operational result having an important influence on the PER's evolution.

\section{Bibliography}

1. Anghelache, G.(2009). Piata de capital in context european. Economic Publisher House.

2. Baltes, N., Dragoe, A. G. M., Ardelean, D. I. (2014). Study regarding the determination of the financial performance of a company through market rates. Studia Universitatis "Vasile Goldis" Arad, No. 3, Volume 24, pp. 1-10, publicatii.uvvg/index.php/studiaeconomia.

3. Clark, M. (2013). A comparison of correlation measures. Center for Social Research, University of Notre Dame, pp.4.

4. Gust, M. (2014). Consequences and influences of the economic crisis on the efficiency of Romanian enterprises. Studia Universitatis "Vasile Goldis" Arad, Vol 24 Issue 3, pp. 37-46, publicatii.uvvg/index.php/studiaeconomia.

5. Catoiu, I. (2009). Marketing Research, Uranus Publishing House, Bucuresti.

6. Field, A.(2005). Discovering Statistics Using SPSS. Second Edition, Sage Publishing

7. Hauke J., Kossowski T. (2011). Comparison of values of Pearson's and Spearman's correlation coefficient on the same sets of data. Quaestiones Geographicae, 30(2), Bogucki Wydawnictwo Naukowe, Poznań, pp. 87-93, http://geoinfo.amu.edu.pl/qg/archives/2011/qg302_087-093.pdf.

8. Helfert, E. (2001). Financial Analysis Tools and Techniques - A Guide for Managers. USA: McGraw Hill.

9. Estrada, J. (2005). Adjusting P/E ratios by growth and risk: the PERG ratio. International Journal of Managerial Finance, Vol. 1, No. 3, pp. 187-203 IESE Business School, Barcelona, Spain, Emerald Group Publishing Limited.

10. Kenneth, M. \& Ambrose, J.(2014). Price to Book Value Ratio and Financial Statement Variables (An Empirical Study of Companies Quoted At Nairobi Securities Exchange, Kenya). Global Journal of Commerce \& Management Perspective, Published by: Global Institute for Research \& Education, www.gifre.org, G.J.C.M.P.,Vol.3(6), pp: 50-56, ISSN: 2319 - 7285.

\section{DE GRUYTER}

OPEN 
11. Lilea, E., Vatui, M., Boldeanu, D., Goschin, Z.(2006). Applied Statistics in Economics. Oscar Print Publishing House, Bucuresti: www.bibliotecadigitala.ase.ro

12. Naidin, M.(2011). Introducere in SPSS - note de curs.

13. Roman, M. Statistica financiar bancara, Chapter no. 6: Analiza Statistica a rentabilitatii si riscului titlurilor individuale, (http://www.bibliotecadigitala.ase.ro/biblioteca/carte2.asp?id=277\&idb=).

14. Ruthenberg, D. (Israel), Pearl, S. (Israel), Landskroner, Y. (Israel) (2011). Factors affecting stock market performance with special reference to market-tobook ratio in banking - the Israeli case. Banks and Bank Systems, Volume 6, Issue 1 , pp. $87-98$.

15. Shen, P. (2000). The P/E Ratio and Stock Market Performance. Economic Review, Fourth Quarter, pp. 23-36.

16. Tichindelean, M.(2014). Marketing relational, Pro Universitaria Publisher House.

17. www.tradeville.eu

18.

http://www.bvb.ro/info/Rapoarte/Ghiduri/ghidul\%20companiei\%20listate\%20RO $\% 20$ web.pdf

19. http://www.bvb.ro/info/Rapoarte/Anuale/BSERapAn2007.pdf

20. http://www.bvb.ro/info/Rapoarte/Anuale/BSERapAn2008.pdf

21. http://www.bvb.ro/info/Rapoarte/Anuale/BVB_Raport-anual-2009-22.09.2010web.pdf

22. http://www.bvb.ro/info/rapoarte/anuale/bvb_raport-anual-2010-web.pdf

23. http://www.bvb.ro/info/Rapoarte/Anuale/BVB-Raport-anual-2011-web.pdf

24. http://www.bvb.ro/info/Rapoarte/Anuale/BVB-Raport-anual-2012-RO-web.pdf 25. http://www.bvb.ro/info/Rapoarte/Anuale/BVB-Raport-anual-2013-RO.pdf 